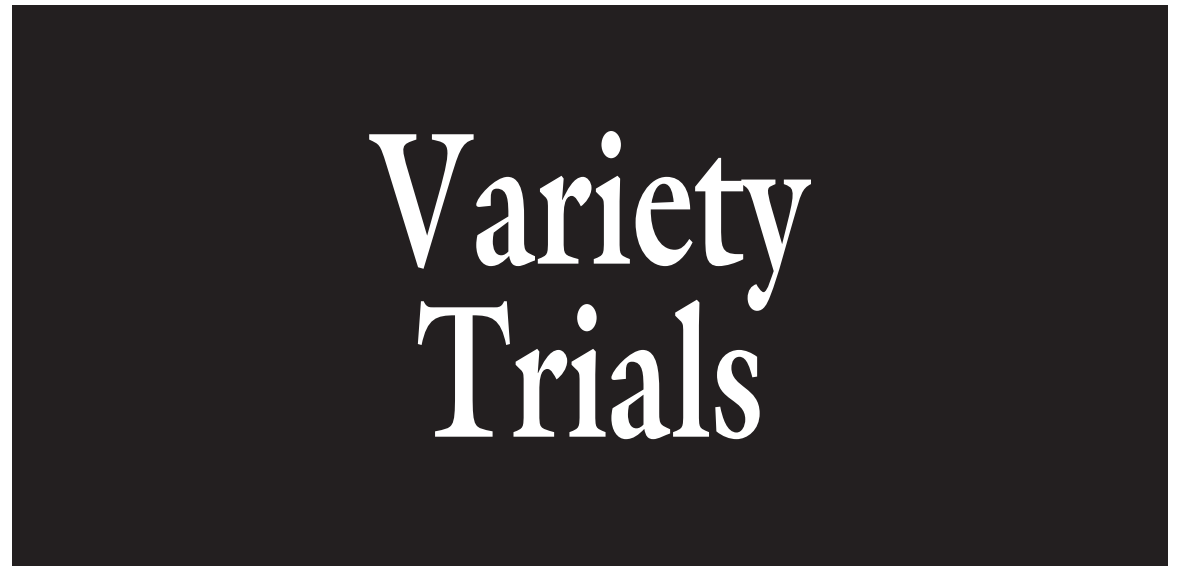

\title{
Performance of Hazelnut Cultivars from Oregon in Northeastern Slovenia
}

\author{
Anita Solar ${ }^{1,3}$ and Franci Ś ${ }^{2} a m p a r{ }^{2}$
}

AdDitional Index words. Corylus avellana, phenology, nut and kernel quality, weevil, climatic adaptation

Summary. Three cultivars and three selections from Oregon State University's (OSU) hazelnut (Corylus avellana) breeding program were investigated in a yield trial during the period 1997 to 2007 in northeastern Slovenia with the Italian 'Tonda Gentile delle Langhe' as the standard. All OSU genotypes had higher cumulative yield and yield efficiency than the standard, all exceeded the kernel percentage of $45 \%$, and all had at least $76 \%$ good kernels. OSU 228.084 is promising due to good vegetative growth and the highest yields and yield efficiency. It set many catkins and had the highest percentage of marketable kernels. Its disadvantage could be early flowering and large yield reduction due to low temperatures in early spring. Cultivars/selections that were late flowering ('Lewis' and OSU 244.001) had longer durations of pistillate flower receptivity ('Willamette' and OSU 238.125) and had lower sensitivity to unfavorable weather conditions in early spring ('Clark') expressed the best climatic adaptation. Unmarketable nuts were mainly blanks and poorly filled nuts. 'Clark' is precocious early maturing, and well-suited to the kernel market. Due to its upright growth habit, 'Clark' could be planted more densely than others. 'Lewis' yielded well and had medium yield efficiency, and is suitable for in-shell and kernel markets. Excellent pellicle removal was observed in OSU 244.001 and OSU 238.125. All OSU cultivars and selections showed relatively low susceptibility to hazelnut weevil (Balaninus nucum).

$\mathrm{H}$ azelnut belongs to the group of nut tree species that bear highly nutritious fruits. Edible kernels, protected with lignified shells, have a mild, sophisticated flavor that is sweet, rich, buttery, and smoky. They provide a good balance of protein, carbohydrates, and fats,

${ }^{1}$ Department of Agronomy, Biotechnical Faculty, University of Ljubljana, Experimental Field for Nut Crops Maribor, Vinarska 14, SI-2000 Maribor, Slovenia

${ }^{2}$ Department of Agronomy, Biotechnical Faculty, University of Ljubljana, Jamnikarjeva 101, SIl000 Ljubljana, Slovenia

This work is a part of the program Horticulture No. P4-0013-0481 granted by the Slovenian Ministry of Higher Education, Science, and Technology.

${ }^{3}$ Corresponding author. E-mail: anita.solar@bf.uni-lj.si. and are also a healthy source of vitamin $\mathrm{E}$, folate, $\mathrm{B}$ vitamins, lowdensity lipoprotein (LDL) cholesterollowering unsaturated fatty acids, and blood pressure-lowering minerals. Kernels are also a rich source of energy, magnesium, potassium, protein, and fiber (Hazelnut Council, 2007). New dietary guidelines issued jointly by the U.S. Department of Agriculture (USDA) and the U.S. Department of Health and Human Services suggest consuming 30 to 35 kernels $(1.5 \mathrm{oz})$ of hazelnuts four to five times per week to reduce the risk of heart disease (U.S. Food and Drug Administration, 2003).

Hazelnuts are a part of healthy diets such as the Mediterranean diet and are more and more in demand by well-informed consumers who want to eat healthier foods. Indeed, hazelnut consumption has increased in recent decades (Tous, 2001). Because the hazelnut can be grown in a wide range of climates, several "new" countries from northern latitudes and the southern hemisphere who are now major importers of hazelnuts have already started to plant their own commercial orchards. They consider it an opportunity for import replacement, and for cultivation and distribution of their own fresh hazelnuts. One of the basic decisions when establishing a new plantation is selecting the most appropriate cultivar to meet the demands of the marketplace. Hazelnuts are grown for two markets, kernel and in-shell, and cultivars suitable to each are different. Nuts of small to medium size with crisp kernels are desired by the confectionary industry, while for the in-shell market, large and attractive nuts are considered the best. For kernel and in-shell markets, nuts should be wellfilled, have thin shells, round shapes, few defects, and a long shelf life (Mehlenbacher, 1991). These are the objectives of breeding programs (Botu et al., 2005; McCluskey et al., 1997, 2001, 2005, 2008; Okay and Özenc, 2001; Romisondo et al., 1976; Thompson, 1974; Valentini et al., 2001), as well as when selecting from the wild (Karadeniz et al., 1997;

\begin{tabular}{llll}
\hline $\begin{array}{l}\text { Units } \\
\text { To convert U.S. to SI, } \\
\text { multiply by }\end{array}$ & U.S. unit & SI unit & $\begin{array}{l}\text { To convert SI to U.S., } \\
\text { multiply by }\end{array}$ \\
\hline 0.3048 & $\mathrm{ft}$ & $\mathrm{m}$ & 3.2808 \\
2.54 & inch(es) & $\mathrm{cm}$ & 0.3937 \\
25.4 & inch(es) & $\mathrm{mm}$ & 0.0394 \\
6.4516 & inch ${ }^{2}$ & $\mathrm{~cm}^{2}$ & 0.1550 \\
0.4536 & lb & $\mathrm{kg}$ & 2.2046 \\
0.0703 & lb/inch & $\mathrm{kg} \cdot \mathrm{cm}^{-2}$ & 14.2233 \\
28.3495 & $\mathrm{oz}$ & $\mathrm{g}$ & 0.0353 \\
$\left({ }^{\circ} \mathrm{F}-32\right) \div 1.8$ & ${ }^{\circ} \mathrm{F}$ & ${ }^{\circ} \mathrm{C}$ & $\left(1.8 \times{ }^{\circ} \mathrm{C}\right)+32$
\end{tabular}


Rovira et al., 2005; Schepers and Kwanten, 2005; Xie et al., 2005). Because about $90 \%$ of the world's hazelnuts are used for industrial purposes (Germain and Sarraquigne, 2004; Tous, 2001), cultivars suitable for the confectionary industry are favored in new plantings.

In this study, we describe the behavior of six American genotypes in northeastern Slovenia, which has a continental climate typical of central Europe. We expect that this information about new genotypes, little known in Europe, will be used in the choice of cultivars for new commercial orchards in Slovenia and nearby countries with similar growing conditions, as well as U.S. states that have similar climates to continental Europe, taking into account USDA plant hardiness zones (U.S. National Arboretum, 2003).

\section{Materials and methods}

The research was carried out in a level field at the Biotechnical Faculty in Maribor, northeastern Slovenia (lat. $46^{\circ} 32^{\prime} \mathrm{N}$, long. $15^{\circ} 39^{\prime} \mathrm{E}$, elevation $275 \mathrm{~m}$ ), on shallow, rather acidic soil with medium organic matter content, and clay loam texture. This region has typical continental weather conditions with a mean annual temperature of $9.7^{\circ} \mathrm{C}$, an absolute summer maximum of $35.8{ }^{\circ} \mathrm{C}$, and a winter minimum of $-22.3{ }^{\circ} \mathrm{C}$ (MOP, ARSO, 2008). Long-term averages (1961-90) are $1799 \mathrm{~h}$ of sun irradiation and $1046 \mathrm{~mm}$ of rainfall. Its distribution is continental with two peaks: in summer (July and August), and late autumn (November). Over the last 15 years, a slight tendency for increased mean air temperature and decreased precipitation has been evident. Average annual minimum temperature (1991-2006) is between -0.2 and $-6.4{ }^{\circ} \mathrm{C}$ (MOP, ARSO, 2006).

Three hazelnut cultivars (Lewis, Clark, and Willamette) and three advanced selections (OSU 228.084, OSU 238.125, and OSU 244.001), all from the Oregon State University breeding program, were planted in late Spring 1997. They are suited to the kernel market, as is the highly valued Italian 'Tonda Gentile delle Langhe' (TGDL), which was included as the standard in the trial. One-year-old rooted plants propagated according to the tie-off method were planted at a spacing of $5 \times 4 \mathrm{~m}$. Three replicates of each genotype were planted in a randomized complete block design. During the first years after planting, they were trained as bushes with four to six main branches. Herbicides were applied twice per year to the soil under the bushes within the rows, while between the rows, the grass was cut four to five times per year. The orchard was not irrigated, and was modestly fertilized with nitrogen, potassium, and phosphorous.

Data were collected on each individual plant starting in 1999. Traits relating to phenology, yield, nuts, kernels, and health status were observed each year. Leafing dates were recorded at the phenological stage C (Germain and Sarraquigne, 2004), male flowering at stages Fml (start), Fm2 (peak), and Fm3 (end), and female flowering at stages Ffl (start), Ff2 (peak), and Ff3 (end). The amount of flowering was rated from 1 (no flowers) to 9 (many). Time of nut drop was from the harvesting of the first $100 \mathrm{~g}$ to the last $100 \mathrm{~g}$ of mature nuts. The nuts were dried in a wooden dryer at $35^{\circ} \mathrm{C}$ to $\approx 12 \%$ moisture content. One hundred in-shell nuts per cultivar were measured, in millimeters, for their length, width, and thickness, using a caliper. Shape index (SI) was calculated according to the equation: $\mathrm{SI}=$ $[$ (width + thickness $) / 2 \times$ length $]$. Nuts were cracked by hand. After cracking, shell thickness was measured in millimeters on the convex side of each half using a caliper. Kernel percentage $(\mathrm{PK})$ was calculated as $[$ (kernel weight/nut weight $) \times 100]$. The percentage of empty nuts (blanks) and defects such as brown stain, shriveled kernels, moldy kernels, and twins was calculated. The amount of kernel fiber was rated from $\mathrm{l}$ (thick, around the whole kernel) to 9 (very thin, in traces). Kernel blanching was rated after roasting at $130^{\circ} \mathrm{C}$ for 15 min (McCluskey et al., 1997) on a scale of 1 (no pellicle removal) to 9 (complete removal) (International Plant Genetic Resources Institute, 2008). The collected data also included yield per tree, circumferences of each main branch, and percentage of nuts infested by hazelnut weevil. This article summarizes data collected over 8 years (2000-07). At the end of the observation period, the heights and the widths of the plants were measured. Finally, cumulative yield/ plant (CY), trunk cross-sectional area (TCSA), and yield efficiency (YE) were calculated for each cultivar. TCSA was the sum of the cross-sectional areas of all main branches of the bush, $30 \mathrm{~cm}$ above the ground. YE is the ratio of cumulative yield (2000$07)$ to TCSA measured in 2007. Differences among the cultivars and years were evaluated using multifactor (year, cultivar) analysis of variance and Duncan's multiple range test $(P=$ $0.05)$.

\section{Results and discussion}

Phenology. The first flowers (male and female) appeared in the precocious 'Clark' 3 years after planting. At the same age, catkins were first seen on 'Lewis'. In other genotypes, the first flowers were noted in the fourth year. Over the 8 years (200007), 'Lewis' and OSU 228.084 set the largest amount of the catkins and female flowers, respectively. For OSU genotypes, flowering was concentrated in the first and second $10-\mathrm{d}$ periods of March (Fig. 1), while TGDL flowered about 3 weeks earlier. As reported by Baldwin et al. (2005), in Australia, the difference between TGDL and 'Willamette' regarding their times of pollen shedding and the beginning of female bloom was only 3 and $9 \mathrm{~d}$, respectively. In our study, cultivars were homogamous. Only 'Lewis' and OSU 244.001 had their peaks of male and female flowering $4 \mathrm{~d}$ apart, while in all other cultivars, the overlapping of both types of inflorescences was $\pm 1 \mathrm{~d}$. Homogamy was also reported for 'Lewis' and 'Willamette' growing in Catalonia, Spain (Rovira and Tous, 2001). Catkins of OSU 228.084 were the earliest to elongate and shed pollen, while OSU 244.001 was the latest. Flowering dates are in agreement with those reported by Mehlenbacher et al. (2001) for Oregon. Female flowers were receptive between 3 March (OSU 228.084) and 17 March ('Willamette', 'Lewis', OSU 244.001, and OSU 238.125). In our case, female receptivity in 'Lewis' and 'Clark' was almost at the same time, but in Oregon, 'Clark' is reported as later than 'Lewis' (Mehlenbacher et al., 2000, 2001). Leaf budbreak was earliest in TGDL (24 March) and was latest in OSU 244.001 and 'Willamette' (6 


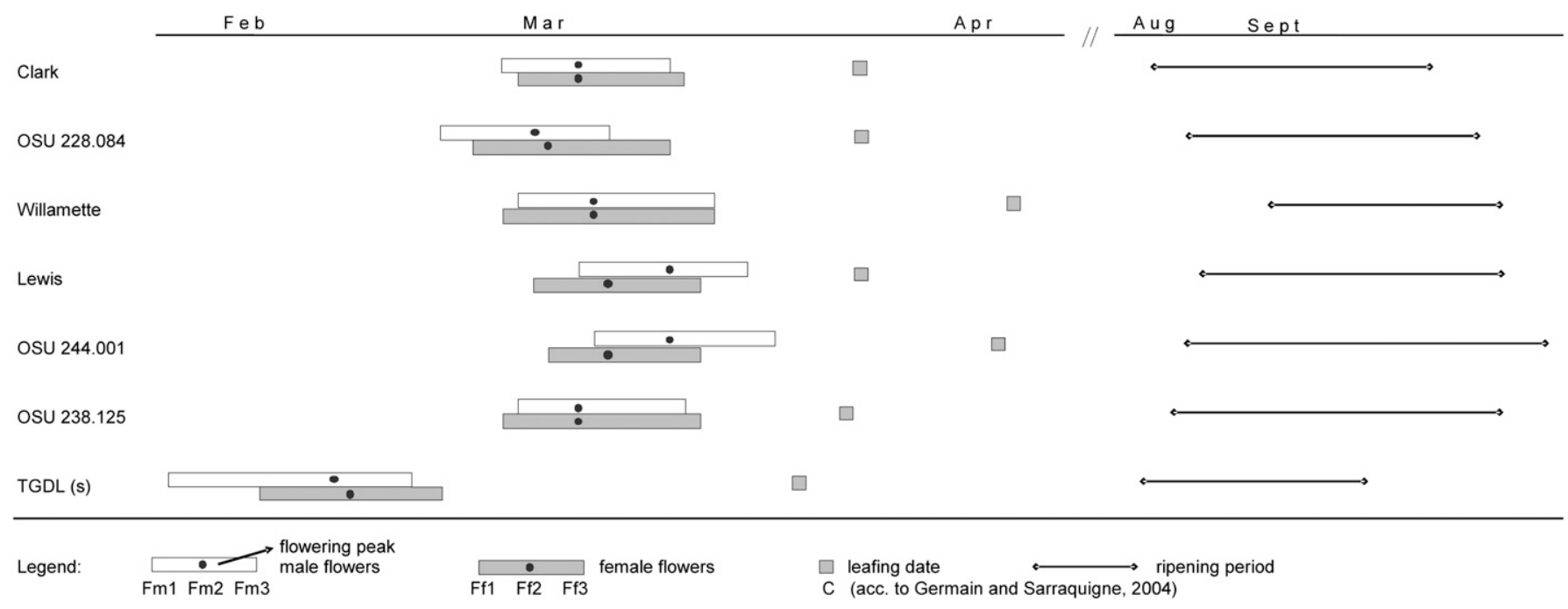

Fig. 1. Average date of flowering (male inflorescences: Fml = start, Fm2 = peak, Fm3 = end; female flowers: Ffl = start, Ff2 = peak, Ff3 = end), leafing out (C), and ripening period (day-interval) observed in hazelnut cultivars Clark, Willamette, Lewis, Tonda gentile delle Langhe [TGDL (used as the standard)], and selections OSU 228.084, OSU 244.001, and OSU 238.125 at Maribor, Slovenia, during a 9-year period (1999-07).

and 7 Apr., respectively). The period of nut drop was the shortest in 'Willamette' (12 d). In the other genotypes, nuts dropped over a period of 15 to $18 \mathrm{~d}$, with the longest period observed in OSU 244.001. Among the American cultivars, nuts of 'Clark' were the earliest to ripen.

YIELD. The first crop (more than $100 \mathrm{~g}$ of nuts per plant) was recorded 4 years after planting in all cultivars except the standard TGDL (Fig. $2)$. The highest yield was recorded for OSU $238.125(9.1 \mathrm{~kg} /$ plant $)$ in the eighth year and 'Lewis' $(8.9 \mathrm{~kg}$ / plant) in the 11 th year. OSU 228.084 had the largest cumulative yield (26.5 $\mathrm{kg} /$ plant), and was followed by OSU $238.125(23.1 \mathrm{~kg} /$ plant $)$ and 'Lewis' (20.9 kg/plant) (Table I). The yields of 'Willamette', 'Clark', and OSU 244.001 were $50 \%$ to $64 \%$ of the yield of OSU 228.084. The cumulative yield of TGDL was only $22 \%$ of that of OSU 228.084. Our results show that in Slovenia, the yield of OSU genotypes was lower than in Oregon. As reported by McCluskey et al. (2001, 2005), and Mehlenbacher et al. (2000, 2001), 'Clark' and 'Lewis' gave 20 to $25 \mathrm{~kg} /$ plant in the first 8 years after planting. A high cumulative yield was also noted for 'Willamette' and OSU 238.125. In Oregon, 'Willamette' yields were between $16.5 \mathrm{~kg} /$ plant (McCluskey et al., 2005) and $23.8 \mathrm{~kg} /$ plant (Mehlenbacher et al., 2000) in the first 7 years, while in Slovenia, over the period of 11 years, the same cultivar bore only $13.2 \mathrm{~kg} /$ plant. In Oregon, OSU 238.125 yielded 7.3 $\mathrm{kg} /$ plant in the first 5 years (McCluskey et al., 1997), while in Slovenia, this level was not exceeded until the seventh or eighth year after planting. The differences in the nut yield may be attributed to three main reasons. First, our trial consisted of 1 -year-old rooted layers, received from the breeders, whereas in Corvallis, OR, 2 -year-old well-rooted trees were planted in the trials (McCluskey et al., 2001). Second, the Slovene experimental orchard was not irrigated, while in Oregon, young trees were provided with supplemental overhead irrigation throughout the first five growing seasons (McCluskey et al., 2001). Third, during the 11year period of our trials in Slovenia, we had two periods of cold weather, which decreased nut yield. The first was 6 years after planting (2002), and the second was 9 years after planting (2005) (Fig. 2). In both years, a certain number of female flowers froze due to low temperatures in March, after a very warm January and February. In 2002, nut yield per plant decreased by $87 \%$ in 'Lewis' and $26 \%$ in OSU 238.125 compared with the previous year. However, 'Clark'

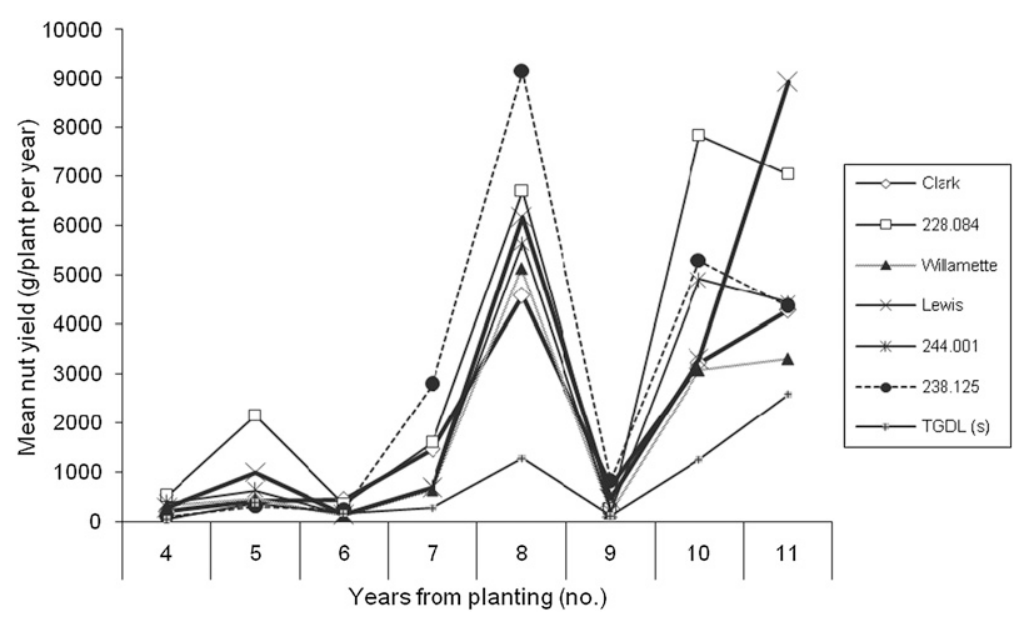

Fig. 2. Mean nut yield evaluated in the 4th to 11 th years from planting in hazelnut cultivars Clark, Willamette, Lewis, Tonda gentile delle Langhe [TGDL (used as the standard)], and selections OSU 228.084, OSU 244.001, and OSU 238.125, Maribor, Slovenia (1 $\mathrm{g}=\mathbf{0 . 0 3 5 3} \mathrm{oz})$. 
Table 1. Height and width of the plants, trunk cross-sectional area (TCSA), cumulative nut yield, and yield efficiency evaluated in four cultivars and three selections of hazelnut at Maribor, Slovenia. Cumulative yield is presented as the 8-year (2000-07) average, while the other data were obtained at the end of the observation period (2007).

\begin{tabular}{|c|c|c|c|c|c|}
\hline \multirow[b]{2}{*}{ Cultivar or selection } & \multicolumn{2}{|c|}{ Plant dimensions (2007) } & \multirow{2}{*}{$\begin{array}{c}\text { TCSA } \\
2007\left(\mathrm{~cm}^{2}\right)^{\mathrm{z}}\end{array}$} & \multirow{2}{*}{$\begin{array}{c}\text { Cumulative yield } \\
2000-07(\mathrm{~kg} / \text { plant })^{\mathrm{z}}\end{array}$} & \multirow{2}{*}{$\begin{array}{l}\text { Yield efficiency } \\
2007\left(\mathrm{~kg} \cdot \mathrm{cm}^{-2}\right)^{\mathrm{z}}\end{array}$} \\
\hline & $\mathrm{Ht}(\mathrm{m})^{\mathrm{z}}$ & Width (m) & & & \\
\hline Clark & $3.3 b^{y}$ & $2.9 \mathrm{a}$ & 185.4 & $15.3 \mathrm{bc}$ & 0.08 \\
\hline OSU 228084 & $2.9 \mathrm{a}$ & $4.0 \mathrm{c}$ & 203.7 & $26.5 \mathrm{de}$ & 0.13 \\
\hline Willamette & $3.1 \mathrm{~b}$ & $3.3 \mathrm{ab}$ & 189.2 & $13.2 \mathrm{~b}$ & 0.07 \\
\hline Lewis & $3.7 \mathrm{c}$ & $3.2 \mathrm{ab}$ & 209.6 & $20.9 \mathrm{~d}$ & 0.10 \\
\hline OSU 244001 & $3.5 \mathrm{bc}$ & $3.9 \mathrm{c}$ & 208.4 & $17.0 \mathrm{bc}$ & 0.08 \\
\hline
\end{tabular}

${ }^{\mathrm{z}} \mathrm{l} \mathrm{m}=3.2808 \mathrm{ft}, \mathrm{l} \mathrm{cm}{ }^{2}=0.1550$ inch $^{2}, \mathrm{l} \mathrm{kg}=2.2046 \mathrm{lb}, \mathrm{l} \mathrm{kg} \cdot \mathrm{cm}^{-2}=14.2233 \mathrm{lb} /$ inch $^{2}$.

${ }^{y}$ Means within a column followed by the same letter are not significantly different via Duncan's multiple range test at $P \geq 0.05$

${ }^{x} \mathrm{TGDL}=$ the cultivar Tonda gentile delle Langhe used as the standard.

did not suffer due to the cold weather. In fact, it even had a slightly higher yield than the previous year. 'Clark' was also less susceptible to cold weather in 2005. In comparison with 2004, the yield of 'Clark' was reduced by $83 \%$, while in all other cultivars, the reduction was higher than $90 \%$. Nut yield efficiency, a measure of productivity that takes plant size into account, ranged from 0.03 to $0.13 \mathrm{~kg} \cdot \mathrm{cm}^{-2}$ (Table 1). It was the highest for OSU 228.084, which gave the highest cumulative yield on low and very wide bushes. Its yield efficiency was twice that of 'Willamette' and four times that of TGDL. Low nut yield efficiency for TGDL was also reported by McCluskey et al. (1997) in Oregon, Santos and Silva (2001) in Portugal, and Grau and Bastias (2005) in Chile. 'Clark', OSU 244.001, and OSU 238.125 had similar nut yield efficiency, while the YE of 'Lewis' was $125 \%$ of these three genotypes. In Oregon, 'Willamette' was more efficient than OSU 238.125, 'Lewis', and OSU 228.084 (McCluskey et al., $1997,2005)$, which is the opposite of our results.

VEGETATIVE GROWIN G CHARACTERISTICS. At the end of the experimental period (11th growing season), the bushes of 'Clark' were the smallest. They measured $3.3 \mathrm{~m}$ in height and $2.9 \mathrm{~m}$ in canopy diameter (Table 1) and had the lowest TCSA. The small size of 'Clark', which would allow for high-density plantings, was also reported by Mehlenbacher et al. (2001). In contrast, bushes of OSU 228.084 were low $(2.9 \mathrm{~m})$ and wide $(4.0 \mathrm{~m})$, and would have to be planted at larger distances. Vigorous growth that resulted in wide bushes of intermediate height was characteristic of OSU 238.125 and OSU 244.001. 'Lewis' had an upright-spreading growth habit, as noted by Mehlenbacher et al. (2000).

Nut AND Kernel QUALITY. Nut weight ranged from 1.94 to $2.40 \mathrm{~g}$ (Table 2). Nuts of 'Clark' and OSU 228.084 were significantly smaller than all other cultivars. Nuts of 'Lewis' were the largest $(2.4 \mathrm{~g})$. Compared with Oregon (McCluskey et al., 2001, 2005; Mehlenbacher et al., 2000, 2001), the average nut weights in Slovenia were lower for 'Clark' and 'Lewis' by $\approx 20 \%$, which could be due to the absence of irrigation in our trial. As already reported (Solar and Stampar, 2008), interyear variability expressed in the difference between maximum and minimum nut weights was from 0.9 to $1.2 \mathrm{~g}$ in all cultivars except 'Willamette', which was less variable. Nut weight is related to crop load. In the heavy crop year of 2006, nuts weighed from $16 \%$ ('Lewis') to $28 \%$ (OSU 228.084) less than in the light crop year 2005 (Solar and Stampar, 2008). This relationship corresponds with the results of McCluskey et al. (2001). The nut shells of 'Clark', OSU 228.084, and OSU 238.125 measured less than $1 \mathrm{~mm}$ in thickness (Table 2). In other cultivars, they did not exceed $1.15 \mathrm{~mm}$. To our knowledge, there is no other data about the shell thicknesses of OSU cultivars. Taking into account some other cultivars that had shells of $1.07 \mathrm{~mm}$ ('B6') to $1.62 \mathrm{~mm}$ ('Barcelona') in thickness (Valentini et al., 2005), we can expect OSU cultivars to be easier to crack and need less time for drying. All of the cultivars had similar shapes, as indicated by the nut shape index. Despite this, there were statistically significantly differences among them. The values ranged from 0.92 for 'Willamette' and OSU 244.001 to 1.00 for OSU 238.125, indicating round shape (Mehlenbacher, 1991) and suitability for the kernel market. Kernel percentage (Table 2) was highest $(53.1 \%)$ in OSU 238.125, followed by 'Clark' (50.4\%), 'Lewis' (48.0\%), and 'Willamette' (47.5\%). Mehlenbacher et al. $(2000,2001)$ obtained similar values for 'Lewis' and 'Clark', while for OSU 238.125 and 'Willamette', a higher percentage of kernel was reported by McCluskey et al. (1997). Our value for 'Lewis' was similar to that reported by Rovira and Tous (2001) in Tarragona, Spain. As for nut weight, kernel percentage depended on crop load. The largest variation was observed in 'Clark' and OSU 228.084, where in the year 2005 (light crop), the percentage of kernel was nearly $10 \%$ higher than in the following year (heavy crop). Raw kernels had little fiber on the pellicle in all OSU genotypes, and thus these cultivars would be not only suitable for the kernel market but also for the in-shell market. The fiber imparts a bitter flavor and detracts from the appearance of the kernel (Mehlenbacher, 1991). From the kernels of OSU 238.125, OSU 244.001, and TGDL, almost all the pellicle was removed after roasting. In 'Clark', more than half of the pellicle was removed, while about half was removed in 'Willamette' and 'Lewis'. Similar ratings were reported in Oregon (McCluskey et al., 1997, 2005; Mehlenbacher et al., 2001). The percentage of good nuts ranged from $75.8 \%$ in the standard TGDL to $88.0 \%$ in OSU 228.084 (Table 2). 


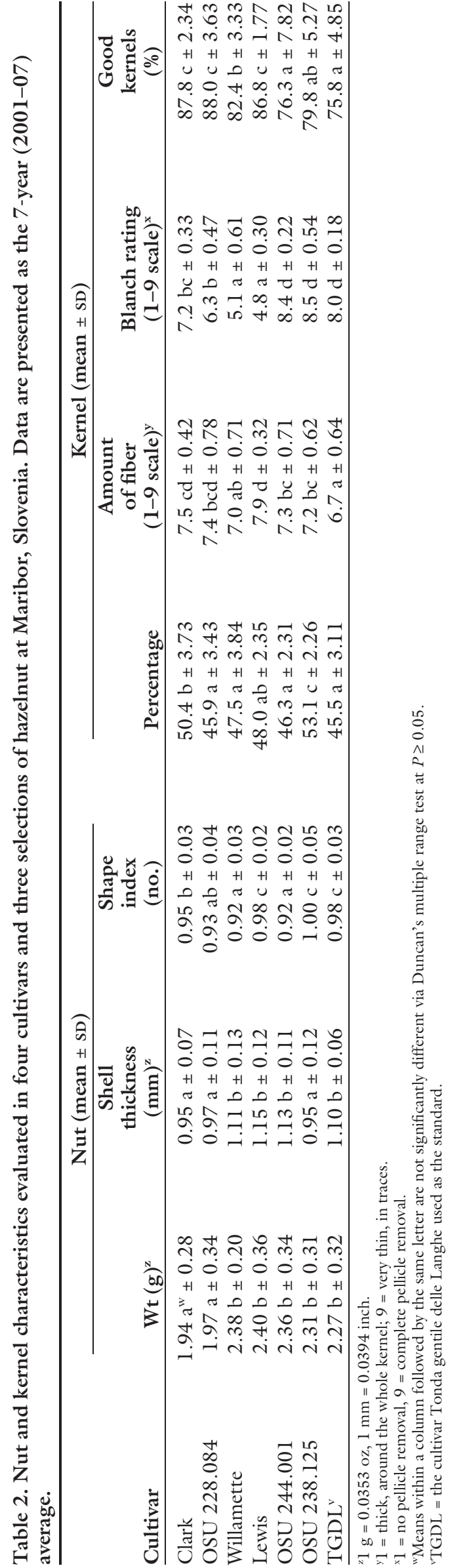

'Clark' and 'Lewis' also produced a significantly higher percentage of good kernels than 'Willamette', OSU 238.125, and OSU 244.001. Average values observed in Oregon were lower than ours for 'Willamette', 'Lewis', and 'Clark' (Mehlenbacher et al., $2000,2001)$. Large interyear variability was found in both areas. In Slovenia, the largest fluctuation was observed for OSU 244.001 (52.5$96.5 \%$ good nuts). In all cultivars, at least three-quarters of the defects were blanks or poorly filled nuts, which correspond to the results in Oregon (Mehlenbacher et al., 2000, 2001).

Weevil damage. During the 7 year period, the percentage of nuts infested by hazelnut weevil was recorded. The hazelnut weevil is the main hazelnut pest in Europe (AliNiazee, 1997), but is not present in North America. It affected $1.9 \%$ of the nuts of 'Clark' and OSU 228.084, $3.7 \%$ of 'Willamette' and OSU 238.125 , and $13 \%$ of the nuts of TGDL. In our experimental orchard, the soil under the hazelnut plants was not cultivated, and the conditions for weevil presence and overwintering were favorable. In spite of this, the percentage of damaged nuts was relatively low. It indicates that if OSU cultivars were grown in central European orchards with "grass + herbicide" management, a problem with hazelnut weevil would not be expected.

\section{Conclusions}

Our 11-year investigation of six hazelnut genotypes from Oregon shows that they are quite well-adapted to our conditions in northeastern Slovenia. They could be commercially grown in our region as well as in nearby areas of central Europe with similar growing conditions. In areas where frosts frequently occur during March, 'Lewis' and OSU 244.001 show a slight advantage because of their later flowering (male and female). Similarly, lower frost injury would be expected in OSU 238.125 and 'Willamette' because of the longer duration of pistillate flower receptivity. Many OSU genotypes are cross-compatible. Due to sporophytic incompatibility (Germain et al., 1981; Mehlenbacher, 1997), other effective pollinizers such as 'Epsilon' and 'Zeta' for 'Clark', and 'Tonda di Giffoni' or 'Barcelona', and 'Hall's Giant' for 'Lewis' have been recommended 
(Mehlenbacher and Smith, 2004; Mehlenbacher et al., 2000, 2001). Because of its large set of catkins, 'Lewis' could be a good pollinizer for cultivars without incompatibility alleles S3 and S8, which are determined in 'Lewis' (Mehlenbacher et al., 2000; Mehlenbacher and Smith, 2004). 'Clark' is a desirable cultivar for its early nut maturity, precocity, and lower susceptibility to unfavorable weather conditions in early spring. Two growth habits were observed in these genotypes. The first one, characteristic of 'Clark', was upright bushes that allow high-density plantings. The second growth habit was spreading, observed for OSU 228.084 and OSU 238.125, which would require planting at lower density than 'Clark'. When considering the yield potential, OSU 228.084 was in first place, with regard to the yield at the beginning of the bearing period, as well as to the cumulative yield. It also had the highest nut yield efficiency. All genotypes have round nuts that are suited to the kernel market, while nuts of 'Lewis' and 'Willamette' could also be sold inshell. Although climatic adaptation is rarely a concern in the major production areas, expansion of hazelnut plantings into marginal areas will require the development of adapted cultivars from diverse germplasm (Mehlenbacher, 2008). Our results will be useful to potential growers in Slovenia, and in nearby countries with similar climatic conditions. Considering average annual minimum temperature, the results could also be applicable to USDA hardiness zones $9 \mathrm{a}, 9 \mathrm{~b}$, and a colder part of zone 10a.

\section{Literature cited}

AliNiazee, M.T. 1997. Integrated pest management of hazelnut pests: a worldwide perspective. Acta Hort. 445:469476.

Baldwin, B., K. Gilchrist, and L. Snare. 2005. An evaluation of hazelnut genotypes in Australia. Acta Hort. 686:4756.

Botu, I., E. Turcu, S. Preda, M. Botu, and G. Achim. 2005. 25 years of achievements and perspectives in hazelnut breeding in Romania. Acta Hort. 686:91-94.

Germain, E., P. Leglise, and F. Delort. 1981. Analyse du systeme d'incompatibilite pollinique observe chez le noisetier
Corylus avellana. Proc. $1^{\text {er }}$ Colloque sur les Recherches Fruitieres, Bordeaux. p. 197-215.

Germain, E. and J.P. Sarraquigne. 2004. Le noisetier. Centre technique interprofesionnel des fruits et légumes (CTIFL), Paris.

Grau, P. and R. Bastias. 2005. Productivity and yield efficiency of hazelnut (Corylus avellana L.) cultivars in Chile. Acta Hort. 686:57-64.

Hazelnut Council. 2007. Hazelnut nutritional overview. 6 Feb. 2009. <http:// www.hazelnutcouncil.org/health/ nutritious.cfm>.

International Plant Genetic Resources Institute. 2008. Descriptors for hazelnut (Corylus avellana L.). Biodiversity International, Rome.

Karadeniz, T., F. Balta, R. Cangi, and F. Çelik. 1997. Hazelnut fruit characteristics which are grown at Van Lake region and Hizan. Acta Hort. 445:91-99.

McCluskey, R., A.N. Azarenko, S.A. Mehlenbacher, and D.C. Smith. 1997. Performance of hazelnut cultivars and Oregon State University breeding selections. Acta Hort. 445:13-19.

McCluskey, R., A.N. Azarenko, S.A. Mehlenbacher, and D.C. Smith. 2001. Commercial hazelnut cultivar and advanced selection evaluations at Oregon State University. Acta Hort. 556:89-95.

McCluskey, R., A.N. Azarenko, S.A. Mehlenbacher, and D.C. Smith. 2005. Advanced selections and cultivar performance of hazelnut trials planted in 1994 and 1998 at Oregon State University. Acta Hort. 686:71-78.

McCluskey, R., S.A. Mehlenbacher, D.C. Smith, and A.N. Azarenko. 2008. Advanced selection and new cultivar performance in hazelnut trials planted in 1998 and 2000 at Oregon State University. 7th Intl. Congr. Hazelnut, 23-27 June, Viterbo, Italy. p. 22. (Abstr.).

Mehlenbacher, S.A. 1991. Hazelnuts (Corylus). Acta Hort. 290:791-836.

Mehlenbacher, S.A. 1997. Revised dominance hierarchy for S-alleles in Corylus avellana L. Theor. Appl. Genet. 94:360366.

Mehlenbacher, S.A. 2008. Genetic resources for hazelnut: State of the art and future perspectives. 7 th Intl. Congr. Hazelnut, 23-27 June, Viterbo, Italy. p. 15. (Abstr.).

Mehlenbacher, S.A. and D.C. Smith. 2004. Hazelnut pollenizers 'Gamma', 'Delta', 'Epsilon', and 'Zeta'. HortScience 39:1498-1499.
Mehlenbacher, S.A., A.N. Azarenko, D.C. Smith, and R. McCluskey. 2000. 'Lewis' hazelnut. HortScience 35:314315.

Mehlenbacher, S.A., A.N. Azarenko, D.C. Smith, and R. McCluskey. 2001. 'Clark' Hazelnut. HortScience 36:995996.

MOP, ARSO. 2006 (Ministrstvo za okolje in prostor, Agencija Republike Slovenije za okolje). Povzetki klimatoloških analiz; Letne in mesečne vrednosti za nekatere postaje v obdobju 1991-2006, Maribor. 23 Mar. 2009. <http://www.arso.gov.si/ vreme/podnebje/klimal991_2004.html>.

MOP, ARSO. 2008 (Ministrstvo za okolje in prostor, Age-ncija Republike Slovenije za okolje). Klimatski podatki: Maribor, referenčno obdobje 19611990. 23 Mar. 2009. <http://www.arso. gov.si/vreme/napovedi\%20in\%20podatki/ maribor.htmls.

Okay, A.N. and N. Özenc. 2001. Hazelnut improvement through hybridization. Acta Hort. 556:235-240.

Romisondo, P., G.M.F. Limongelli, and L. Radicati di Brozolo. 1976. Genetic improvement of hazelnut: Investigations and results (in Spanish). Proc. I. Congreso Internacional de Almendra y Avellana, Reus. p. 97-107.

Rovira, M. and J. Tous. 2001. Performance of 17 hazelnut selections from four different breeding programs in Tarragona (Spain). Acta Hort. 556:171-176.

Rovira, M., J. Tous, J.J. Ferreira, and M. Ciordia. 2005. Hazelnut diversity in Asturias (northern Spain). Acta Hort. 686:4145.

Santos, A. and A.P. Silva. 2001. Hazelnut productivity in northern Portugal. Acta Hort. 556:97-101.

Schepers, H.T.A.M. and E.F.J. Kwanten. 2005. Selection and breeding of hazelnut cultivars suitable for organic cultivation in The Netherlands. Acta Hort. 686:87-89.

Solar, A. and F. Štampar. 2008. Inter-year variability of pomological traits evaluated in different hazelnut cultivars in Slovenia. 7th Intl. Congr. Hazelnut, 23-27 June, Viterbo, Italy. p. 109. (Abstr.).

Thompson, M.M. 1974. Progress towards new filbert varieties. Proc. Nut Growers Soc. Oregon Washington 57:47-53.

Tous, J. 2001. World hazelnut production. 6 Feb. 2009. <http://www.wanatca. org.au/acotanc/Papers/Tous-1/ Author-n-Text.htm>.

U.S. Food and Drug Administration. 2003. Qualified health claims: Letter of 
enforcement discretion-Nuts and coronary heart disease. U.S. Food and Drug Administration 14 July:1-4.

U.S. National Arboretum. 2003. USDA plant hardiness zone map. 7 Feb. 2009. <http://www.usna.usda.gov/Hardzone/ ushzmap.html>.
Valentini, N., G. Me, R. Vallania, and G. Zeppa. 2001. New hazelnut selections for direct consumption. Acta Hort. 556:103108.

Valentini, N., L. Rolle, and G. Zeppa. 2005. Characterisation of hazelnut vari- eties by texture analysis. Acta Hort. 686:485-489.

Xie, M., J. Zheng, L. Radicati, and G. Me. 2005 . Interspecific hybridization of hazelnut and performance of 5 varieties in China. Acta Hort. 686:65-70. 